\title{
USE OF SCALED SEMIVARIOGRAMS IN THE PLANNING SAMPLE OF SOIL PHYSICAL PROPERTIES IN SOUTHERN AMAZONAS, BRAZIL
}

\author{
Renato Eleotério de Aquino(1), Milton César Costa Campos(2)*, José Marques Junior(1), \\ Ivanildo Amorim de Oliveira(1), Daniel De Bortoli Teixeira(1) and José Maurício da Cunha(2) \\ (1) Universidade do Estado de São Paulo, Faculdade de Ciências Agrárias e Veterinárias, Departamento de Solos e Fertilizantes, \\ Jaboticabal, São Paulo, Brasil. \\ (2) Universidade Federal do Amazonas, Instituto de Educação, Agricultura e Ambiente, Humaitá, Amazonas, Brasil. \\ * Corresponding author. \\ E-mail: mcesarsolos@gmail.com
}

\begin{abstract}
There is a great lack of information from soil surveys in the southern part of the State of Amazonas, Brazil. The use of tools such as geostatistics may improve environmental planning, use and management. In this study, we aimed to use scaled semivariograms in sample design of soil physical properties of some environments in Amazonas. We selected five areas located in the south of the state of Amazonas, Brazil, with varied soil uses, such as forest, archaeological dark earth (ADE), pasture, sugarcane cropping, and agroforestry. Regular mesh grids were set up in these areas with 64 sample points spaced at $10 \mathrm{~m}$ from each other. At these points, we determined the particle size composition, soil resistance to penetration, moisture, soil bulk density and particle density, macroporosity, microporosity, total porosity, and aggregate stability in water at a depth of 0.00-0.20 m. Descriptive and geostatistical analyses were performed. The sample density requirements were lower in the pasture area but higher in the forest. We concluded that managed-environments had differences in their soil physical properties compared to the natural forest; notably, the soil in the ADE environment is physically improved in relation to the others. The physical properties evaluated showed a structure of spatial dependence with a slight variability of the forest compared to the others. The use of the range parameter of the semivariogram analysis proved to be effective in determining an ideal sample density.
\end{abstract}

Keywords: sample density, spatial variability, physical properties, scaled semivariograms. 


\title{
RESUMO: USO DE SEMIVARIOGRAMAS ESCALONADOS NO PLANEJAMENTO AMOSTRAL DE ATRIBUTOS FÍSICOS DO SOLO EMAMBIENTES NA REGIÃO SUL DO AMAZONAS
}

\begin{abstract}
A carência de informações referentes a levantamento de solos na região sul do Amazonas é muito grande. O uso de ferramentas, como a geoestatistica, pode auxiliar no melhor planejamento, uso e manejo desses ambientes. Neste trabalho, objetivou-se utilizar semivariogramas escalonados no planejamento amostral de atributos físicos do solo em ambientes na região Sul do Amazonas. Foram selecionadas cinco áreas, localizadas ao sul do Estado do Amazonas, com diferentes usos: floresta, terra preta arqueológica (TPA), pastagem, cana-de-açúcar e agrofloresta. Nessas áreas, foram estabelecidas malhas regulares contendo 64 pontos espaçados de 10 m entre si. Determinaram-se composição granulométrica, resistência do solo à penetração, umidade, densidade do solo e das partículas, macro e microporosidade, porosidade total e estabilidade dos agregados em água, nas profundidades de 0,0-0,20 m. Foram realizadas análises estatísticas descritivas e geoestatística. O ambiente que necessitou de menor densidade amostral foi o de pastagem e o que demonstrou a necessidade de maior densidade amostral foi o de floresta. Concluiu-se que os ambientes manejados evidenciaram diferenças nos seus atributos físicos em relação à área de floresta, com destaque a área com TPA que se apresentou melhor fisicamente em relação aos demais. Os atributos físicos avaliados apresentaram estrutura de dependência espacial com pequena variação na sua variabilidade da floresta para os demais ambientes, e o uso do parâmetro alcance do semivariograma se evidenciou eficiente para determinar a densidade amostral ideal.
\end{abstract}

Palavras-chave: densidade amostral, variabilidade espacial, atributos físicos, semivariogramas escalonados.

\section{INTRODUCTION}

Soil in its natural state, under natural vegetation, provides physical conditions that can favor the growth of native species (Andreola et al., 2000). In contrast, the physical properties of cropped soils are altered (Neves et al., 2007), leading to soil degradation (Bertol et al., 2004). Therefore, assessment and monitoring of soil physical properties play an important role in sustainability of agricultural systems (Silva et al., 2005).

Moreover, two close points within the same taxonomic unit may show significant variations in these physical properties (Santos et al., 2012), which may be associated with the management system and the crops planted, but is primarily related to intrinsic soil characteristics (Schaffrath et al., 2008).

Thus, knowing the spatial variability of soil properties is crucial in implementing proper management, including consideration of sampling strategies for soil surveys. For this purpose, geostatistical techniques are used to study the spatial variability of soil and plant properties (Zanão Júnior et al., 2007; Marins et al., 2008; Vieira et al., 2011; Campos et al., 2012, 2013; Camargo et al., 2013; Bottega et al., 2013). However, these techniques require a previous sample design with the exact spatial position of each sample point (Montanari et al., 2012).

One of the great difficulties found in spatial variability studies has been determination of adequate sample spacing to characterize temporal and spatial variations and to represent them accurately, optimizing resources and, consequently, reducing costs (Lima et al., 2010). Thus, studying the characteristics of soil sampling to better define adequate sampling density in distinct environments has been a constant concern of researchers (Lark, 2000; Montanari et al., 2005; Souza et al., 2006; Coelho et al., 2009; Lima et al., 2010).

Considering the limited information on techniques such as geostatistics for the south of the State of Amazonas for mapping soil characteristics and, especially, for designing sample density, the aim of this study was to use scaled semivariograms in sample design of soil chemical properties at five different environments in the south of Amazonas.

\section{MATERIAL AND METHODS}

The study was carried out on farms located in the south of the state of Amazonas in Brazil, some farms near Santo Antônio de Matupi, in the municipality of Manicoré, AM, and others in the municipality of Humaitá, AM. The mapping of five Amazonian soil environments was carried out, namely, anthropic soil or archaeological dark earth (ADE), soil under natural environment or forest, soil under pasture management with brachiaria (Brachiaria brizanta) grass, soil in an agroforestry environment, and soil from a area planted to sugarcane.

The forest area at $7^{\circ} 54^{\prime} 44.5^{\prime \prime} \mathrm{S}, 61^{\circ} 31^{\prime} 44.7^{\prime \prime} \mathrm{W}$ and average altitude of $140 \mathrm{~m}$ is characterized as a dense Tropical Rain Forest fragment with 20 to $50 \mathrm{~m}$ high trees. Surrounding the forest area, there is an area of $\mathrm{ADE}$ at $07^{\circ} 55^{\prime} 02.1^{\prime \prime} \mathrm{S}, 61^{\circ} 31^{\prime} 45.2^{\prime \prime} \mathrm{W}$ 
and 102-m altitude and, at the time of this study, at approximately 120 days after sowing maize. There is also a pasture area at $07^{\circ} 54^{\prime} 42^{\prime \prime S}, 61^{\circ} 31^{\prime} 50^{\prime}$ ” W and average altitude of $135 \mathrm{~m}$ cultivated with brachiaria (Brachiaria brizanta) grass under approximately 10 years of extensive pasture with 1.0 animal ha-1. All these experimental areas are located in Manicoré. The environments located in the municipality of Humaitá are agroforestry at $7^{\circ} 28^{\prime} 29^{\prime \prime} \mathrm{S}, 63^{\circ} 02^{\prime} 07^{\prime \prime} \mathrm{W}$ and $63-\mathrm{m}$ average altitude, with coffee, cocoa, palm trees, and andiroba, among other crops for about 20 years. Finally, there is the sugarcane field at $7^{\circ} 54^{\prime} 38^{\prime}$ ' S, $63^{\circ} 14^{\prime} 27^{\prime \prime} \mathrm{W}$ and 70 -m average altitude under burned sugarcane for 10 years (Figure 1).

Environments in the municipality of Manicoré are on weathered soil originating from Rondonia granite from the Late Precambrian Eon (Brasil, 1978). Yet Humaitá environments have their source material from old alluvial sediments, which are chronologically from the Holocene Epoch (Brasil, 1978). According to the Köppen classification, the climate is rainy tropical with a short dry season $(\mathrm{Am})$, mean temperatures ranging from 25 to $27^{\circ} \mathrm{C}$, and mean annual rainfall from 2,250 to $2,750 \mathrm{~mm}$, with rains concentrated from October to June (Brasil, 1978). Soil types are classified as Red Ultisol in Manicoré and Haplic Cambisol in Humaitá (Embrapa, 2013).

A $70 \times 70$-m grid covering 0.49 ha was set up in these areas. Soil samples were collected at crossover points within the grid, with regular intervals of $10 \mathrm{~m}$, for a total of 64 sample points per grid (Figure 1). These points were georeferenced by Garmin Etrex GPS equipment (South American'69). Subsequently, soil samples were collected from each point in the $0.0-0.1 \mathrm{~m}$ depth layer to analyze soil physical properties. A detailed description of the chemical properties characterization was given by Oliveira et al. (2015).

Particle size analysis was performed by the pipette method using a $0.1 \mathrm{~mol} \mathrm{~L}^{-1} \mathrm{NaOH}$ solution as a chemical dispersant and mechanical shaking at high speed for 15 min as proposed by Embrapa (1997). Total carbon was determined by the Walkley-Black method altered by Yeomans and Bremner (1988).

Undisturbed soil samples for physical analyses were collected by the volumetric ring method, with the use of a $0.045-\mathrm{m}$ ring in the 0.0-0.10-m layer. They were then saturated by the capillary rise method until reaching $2 / 3$ of ring height (tension-table method). Total porosity, microporosity, and macroporosity, and soil bulk density (SBD) were thereby determined by the Embrapa (1997) method; particles density was determined by the volumetric flask method also according to Embrapa (1997).

For aggregate distribution, undisturbed soil blocks were collected from the 0.0-0.10 m layer, air dried, manually broken up into smaller sizes, passed through a $9.52 \mathrm{~mm}$ sieve, and retained in a $4.76 \mathrm{~mm}$ sieve. The retained aggregates were used for determining aggregate stability in water according to Kemper and Chepil (1965), which was performed by placing the samples over a set of sieves with mesh sizes of $2.0,1.0,0.5,0.25$, and $0.063 \mathrm{~mm}$ and then subjecting them to vertical oscillations for 15 min at a frequency of 32 oscillations per minute. Geometric mean diameter (GMD) and weighted mean diameter (WMD) were adopted as stability indices, with calculations made according to Kemper and Rosenau (1986).

Gravimetric moisture content was determined from disturbed soil samples (Embrapa, 1997). Soil resistance to penetration (SRP) was measured by an IAA/Planalsucar impact penetrometer with a $30^{\circ}$ cone angle. Rod penetration into soil (cm per impact) was transformed into SRP according to formula designed by Stolf (1991):

$$
S R P=\frac{M g+m g+\left(\frac{M}{M+m} \frac{M g h)}{x}\right)}{A},
$$

where $\mathrm{SRP}=$ soil resistance to penetration, $\mathrm{kgf} \mathrm{cm}^{-2}$ $\left(\mathrm{kgf} \mathrm{cm}^{-2} \times 0.098=\mathrm{MPa}\right) ; \mathrm{M}_{\mathrm{p}}=$ pounder weight, $4 \mathrm{~kg}$ (Mg - $4 \mathrm{kgf}) ; \mathrm{m}=$ instrument weight without pounder, $3.2 \mathrm{~kg}(\mathrm{Mg}-3.2 \mathrm{kgf}) ; \mathrm{h}=$ height of fall of the pounder, $40 \mathrm{~cm} ; \mathrm{x}=$ rod penetration into soil, $\mathrm{cm} / \mathrm{impact}$, and $\mathrm{A}=$ cone area, $1.29 \mathrm{~cm}^{2}$.

Data was subjected to analysis of variance and mean values were compared by the Tukey test at $5 \%$ probability, which was performed by the Minitab statistical software (Minitab, 2000). Data exploratory analysis was performed by calculating means, median, coefficient of variation (CV), skewness, and the Kolmogorov-Smirnov test. The CV (\%) was calculated based on the Warrick and Nielsen (1980) criterion that classifies the CV as low $(\mathrm{CV}<12 \%)$, medium (from 12-24 \%) and high (CV > $24 \%$ ).

Semivariograms were designed to determine spatial dependence through geostatistics (Matheron, 1963; Vieira et al., 1983; Isaaks and Srivastava, 1989). Under the theory of intrinsic hypothesis, the experimental semivariogram was estimated by equation 2 :

$$
\hat{\gamma}(h)=\frac{1}{2 N(h)} \sum_{i=1}^{N(h)}\left[Z\left(x_{i}\right) \quad Z\left(x_{i}+h\right)\right]^{2}
$$

where $\gamma(\mathrm{h})=$ semivariance value at distance $\mathrm{h}$; $\mathrm{N}(\mathrm{h})=$ number of pairs of experimental Z observations; $\mathrm{Z}\left(\mathrm{x}_{\mathrm{i}}\right)=$ value of the $\mathrm{Z}$ property at location $\mathrm{x}_{\mathrm{i}}$; and $\mathrm{Z}\left(\mathrm{x}_{\mathrm{i}}+\mathrm{h}\right)=$ value of the $\mathrm{Z}$ property separated by $\mathrm{a}$ distance $\mathrm{h}$ from location $\mathrm{x}_{\mathrm{i}}$.

The scaled semivariogram was built based on parameters of experimental semivariograms of soil properties, which were scaled through division of semivariances by statistical variance (Guimarães, 1993; Vieira et al., 1997). In this study, semivariograms were scaled to reduce them to the same scale, facilitating comparison among results of 
different variables. Moreover, we aimed to represent several semivariograms simultaneously to better understand patterns of similarity and causes of spatial variability (Ceddia et al., 2009).

Spherical (Equation 3) and exponential (Equation 4) models were fitted to the scaled experimental semivariograms, which were identified within the figures as Sph. $\left(\mathrm{C}_{0}, \mathrm{C}_{1}+\mathrm{C}_{0},\left[\left(\mathrm{C}_{0} /\left(\mathrm{C}_{0}+\mathrm{C}_{1}\right)\right.\right.\right.$ $\left.\times 100], a, R^{2}\right)$ :

$$
\begin{aligned}
& \left\{\begin{array}{l}
\hat{\gamma}(h)=C_{0}+C_{1}\left[\frac{3}{2}\left(\frac{h}{a}\right)-\frac{1}{2}\left(\frac{h}{a}\right)^{3}\right] \text {, se } 0<h<a \\
\hat{\gamma}(h)=C_{0}+C_{1}, \text { se } h \geq a
\end{array}\right. \\
& \gamma(h)=C_{0}+C_{1}\left[1-\exp \left(-\frac{3 h}{a}\right)\right], h \geq 0
\end{aligned}
$$

where $\mathrm{C}_{0}=$ nugget effect; $\mathrm{C}_{0}+\mathrm{C}_{1}=$ - sill; $\mathrm{h}=$ distance between experimental observations; and $\mathrm{a}=$ spatial dependence range.

Subsequently, scaled semivariograms served as information source to calculate the minimum number of soil samples to determine the variability of all properties within the areas under study (Equation 5):

$$
\mathrm{N}=\frac{\mathrm{A}}{\left(\mathrm{a}^{2}\right) / 10000}
$$

where $\mathrm{N}=$ minimum number of samples necessary to determine a sample grid; $\mathrm{A}=$ total area (ha); and $\mathrm{a}=$ semivariogram range $(\mathrm{m})$.

In analysis of the degree of spatial dependence (DSD) of the variables under study, we used the classification proposed by Cambardella et al. (1994) in which values of $\left[\left(\mathrm{C}_{0} /\left(\mathrm{C}_{0}+\mathrm{C}_{1}\right) \times 100\right]\right.$ lower than

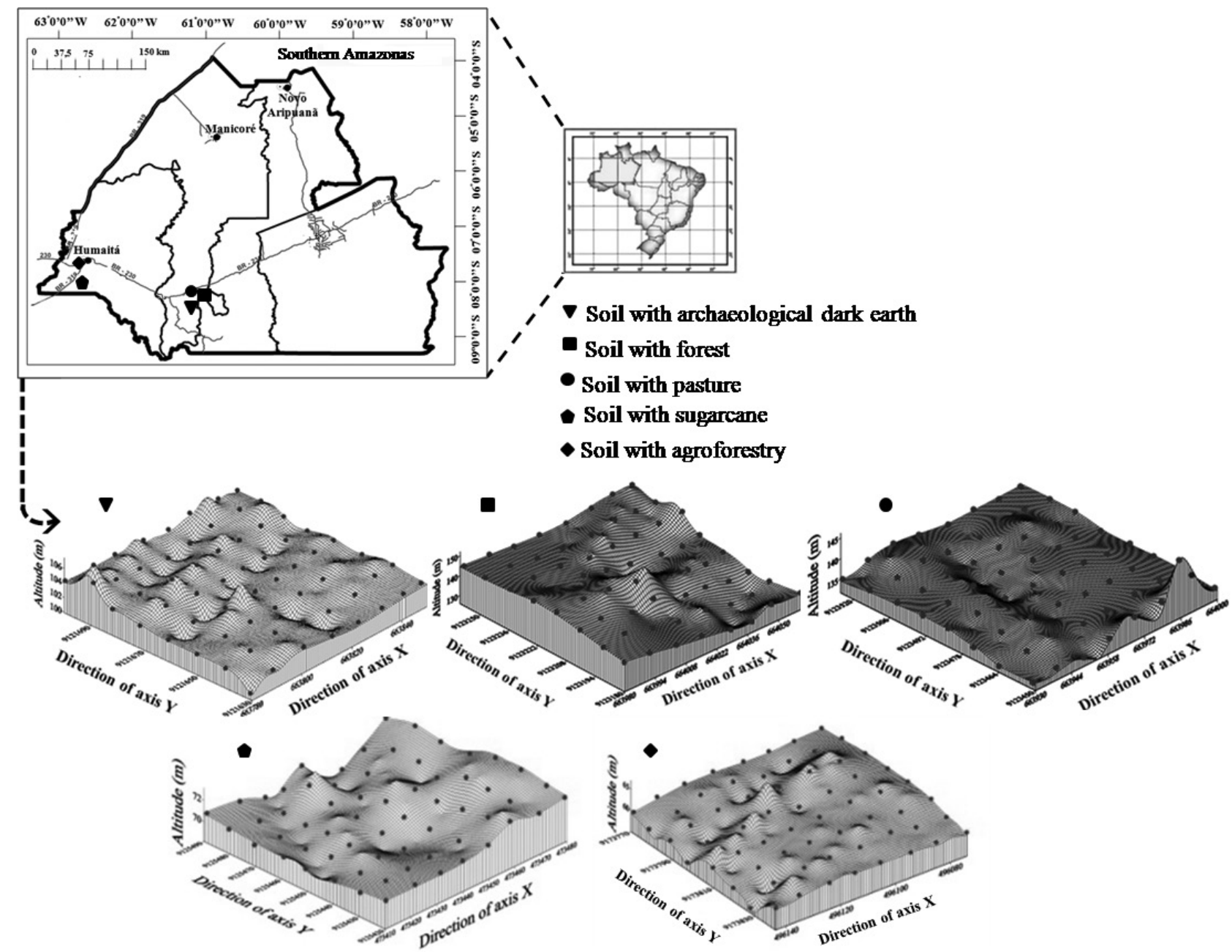

Figure 1. Area location and Digital Elevation Model (DEM) of the environments in southern Amazonas. 
$25 \%$ are considered strongly spatial dependent, values from 25 to $75 \%$ indicate moderate dependence, and values greater than $75 \%$ indicate poor spatial dependence.

\section{RESULTS AND DISCUSSION}

The mean values of the variables under study showed statistical differences among the environments evaluated, especially when compared to the forest (Table 1). Macro- and microporosity, and particles density (PD) of areas with archaeological dark earth (ADE) did not differ from the forest. Moreover, in the pasture area, soil resistance to penetration (SRP) and soil moisture also did not differ statistically from the forest area. It may be observed that ADE has the best soil physical quality, which may be represented by macro- and microporosity, total porosity, soil bulk density (SBD), SRP, and soil moisture in relation to the other areas. In addition, the forest area had values near those registered for the ADE area, as opposed to the others that were managed. These results were observed by Barros et al. (2012), who found values of physical properties in the ADE environment, such as macro- and microporosity, total porosity, SBD, and SRP, which were considered non-limiting to root growth. Steinbeiss et al. (2009), who studied ADE soil, also found similar physical properties considered non-restrictive to root growth. These same authors explained that the low SBD in the $\mathrm{ADE}$ soil areas is due to high levels of organic carbon and intense biological activity (roots and fauna), with digging of tunnels, cavities, and galleries.

It is also important to observe the low macroporosity and high microporosity values in the sugarcane and agroforestry lands (Table 1). This may be explained by the increased silt content in the sugarcane area, and clay in the agroforestry area, which contribute to macropore filling. This leads to higher soil compaction from agricultural practices, as shown by higher SRP values for both areas, whose mean values did not show statistical differences.

The forestry area differed statistically from the other managed environments for variables such as geometric mean diameter (GMD), weighted mean diameter (WMD), and organic carbon (OC). ADE had lower values for GMD and WMD. Soares (2007) found WMD values from 0.9 to $2.2 \mathrm{~mm}$, and GMD values from 0.88 to $1.02 \mathrm{~mm}$. The high OC value in relation to other areas is explained by the anthropogenic origin of $\mathrm{ADE}$, as confirmed by various authors (Campos et al., 2011; Silva et al., 2011; Barros et al., 2012).

It is important to note that increased GMD and WMD values indicate better soil structure stability, although it does not mean these environments are under ideal conditions since most of the results shown for macroporosity (macro) and microporosity (micro), total porosity (TP), SBD, and SRP are restrictive to root development. Bertol et al. (2004) stated that aggregates with high WMD do not always have proper internal pore size distribution.

Table 1. Means test of physical properties for the environments evaluated from the municipalities of Humaitá and Manicoré in the south of Amazonas

\begin{tabular}{|c|c|c|c|c|c|}
\hline Property ${ }^{(1)}$ & Forest & ADE & Pasture & Agroforestry & Sugarcane \\
\hline & \multicolumn{3}{|c|}{ Red Ultisol } & \multicolumn{2}{|c|}{ Haplic Cambisol } \\
\hline Macro (\%) & $21.4 \mathrm{~A}$ & $22.0 \mathrm{~A}$ & $17.1 \mathrm{~B}$ & $2.9 \mathrm{D}$ & $7.0 \mathrm{C}$ \\
\hline Micro (\%) & $19.8 \mathrm{C}$ & $28.4 \mathrm{~B}$ & $20.6 \mathrm{C}$ & $30.9 \mathrm{~A}$ & $29.1 \mathrm{~B}$ \\
\hline $\mathrm{TP}(\%)$ & $41.2 \mathrm{~A}$ & $50.4 \mathrm{~B}$ & $37.7 \mathrm{C}$ & $33.8 \mathrm{D}$ & $36.1 \mathrm{C}$ \\
\hline $\mathrm{SBD}\left(\mathrm{kg} \mathrm{dm}^{-3}\right)$ & $1.3 \mathrm{~B}$ & $0.8 \mathrm{~A}$ & $1.3 \mathrm{C}$ & $1.3 \mathrm{D}$ & $1.2 \mathrm{C}$ \\
\hline $\mathrm{PD}\left(\mathrm{kg} \mathrm{dm}^{-3}\right)$ & $2.6 \mathrm{AB}$ & $2.6 \mathrm{~B}$ & $2.4 \mathrm{C}$ & $2.6 \mathrm{AB}$ & $2.6 \mathrm{~A}$ \\
\hline SRP (MPa) & $2.55 \mathrm{~B}$ & $0.92 \mathrm{C}$ & $2.91 \mathrm{~B}$ & $4.48 \mathrm{~A}$ & $4.46 \mathrm{~A}$ \\
\hline Moisture (kg kg-1) & $21.06 \mathrm{C}$ & $38.30 \mathrm{~A}$ & $24.30 \mathrm{C}$ & $30.91 \mathrm{~B}$ & $32.94 \mathrm{~B}$ \\
\hline GMD (mm) & $2.2 \mathrm{C}$ & $1.7 \mathrm{E}$ & $2.7 \mathrm{~A}$ & $2.0 \mathrm{D}$ & $2.6 \mathrm{~B}$ \\
\hline $\mathrm{WMD}(\mathrm{mm})$ & $2.8 \mathrm{~B}$ & $2.5 \mathrm{C}$ & $3.1 \mathrm{~A}$ & $2.7 \mathrm{~B}$ & $3.1 \mathrm{~A}$ \\
\hline $\mathrm{OC}\left(\mathrm{g} \mathrm{dm}^{-3}\right)$ & $10.82 \mathrm{D}$ & $39.54 \mathrm{~A}$ & $15.92 \mathrm{~B}$ & $11.93 \mathrm{C}$ & $17.68 \mathrm{~B}$ \\
\hline Sand (g kg-1) & $358.8 \mathrm{~B}$ & $434.1 \mathrm{~A}$ & $410.7 \mathrm{~A}$ & $220.7 \mathrm{C}$ & $240.5 \mathrm{C}$ \\
\hline Silt (g kg-1) & $313.2 \mathrm{C}$ & $444.3 \mathrm{~B}$ & $227.6 \mathrm{D}$ & $230.1 \mathrm{D}$ & $474.4 \mathrm{~A}$ \\
\hline Clay (g kg-1) & $327.9 \mathrm{C}$ & $121.5 \mathrm{E}$ & $361.6 \mathrm{~B}$ & $549.0 \mathrm{~A}$ & $284.9 \mathrm{D}$ \\
\hline
\end{tabular}

(1) Macro: macroporosity; Micro: microporosity; TP: total porosity; SBD: soil bulk density; PD: particle density; SRP: soil resistance to penetration; GMD: geometric mean diameter; WMD: weighted mean diameter; OC: organic carbon; and ADE: archaeological dark earth. Mean values followed by the same uppercase letter at the same depth do not differ from each other significantly by the Tukey test at $5 \%$. 
The forest environment differed from the others in terms of particle size. However, predominance of the sand fraction was found in the forest, $\mathrm{ADE}$, and pasture areas, while silt was predominant in the sugarcane area and clay in the agroforestry environment. This may be related to their soil type (Table 1). Martins et al. (2006), Marques et al. (2010), and Campos et al. (2010, 2011) observed similar results in their studies.

Mean and median showed similar values in the forest and ADE environments for all physical properties, except for particle size, which showed statistical distancing for all environments, showing more serious cases of non-symmetric values for these properties (Table 2). Non-symmetric values for physical properties were observed for pasture (macro, TP, SRP, moisture), agroforestry (micro and TP), and sugarcane (macro and TP) areas. Asymmetry follows the same trend as the mean and median values, with distancing from the central value (zero) in physical properties. In this case, all properties have non-symmetric values, and this is more severe for variables such as moisture, GMD, and WMD, with values of $1.18,-2.4$, and -2.8 , respectively. Souza et al. (2004, 2009), studying physical properties of the

Table 2. Descriptive statistics for soil physical attributes in the municipalities of Humaitá and Manicoré in the south of Amazonas

\begin{tabular}{|c|c|c|c|c|c|c|c|c|c|c|c|c|c|}
\hline & Macro & Micro & TP & SBD & PD & SRP & Moisture & GMD & WMD & OC & Sand & Silt & Clay \\
\hline & \multicolumn{2}{|c|}{$\%$} & $\%$ & \multicolumn{2}{|c|}{$\mathrm{kg} \mathrm{dm}{ }^{-3}$} & $\mathrm{MPa}$ & $\mathrm{kg} \mathrm{kg}^{-1}$ & \multicolumn{2}{|c|}{$\mathrm{mm}$} & $\mathrm{g} \mathrm{dm}^{-3}$ & \multicolumn{3}{|c|}{$\mathrm{g} \mathrm{kg}^{-1}$} \\
\hline & \multicolumn{13}{|c|}{ Forest - Red Ultisol } \\
\hline Mean & 21.4 & 19.8 & 41.2 & 1.3 & 2.6 & 2.55 & 21.06 & 2.2 & 2.8 & 10.82 & 358.8 & 313.2 & 327.9 \\
\hline Median & 21.5 & 19.7 & 41.2 & 1.3 & 2.6 & 2.49 & 21.42 & 2.3 & 2.8 & 11.90 & 355.6 & 312.4 & 324.9 \\
\hline CV (\%) & 15.0 & 14.9 & 7.5 & 5.9 & 2.6 & 0.21 & 0.15 & 17.7 & 8.0 & 35.31 & 16.5 & 18.9 & 12.6 \\
\hline Ass. & -0.1 & 0.3 & 0.6 & -0.3 & 0.1 & 1.17 & 0.16 & 0.4 & 0.6 & -0.28 & 1.7 & -1.2 & 0.1 \\
\hline \multirow[t]{2}{*}{$\mathrm{Nt}$} & $0.10^{*}$ & $0.08^{\mathrm{ns}}$ & $0.10^{*}$ & $0.07 \mathrm{~ns}$ & $0.05^{\mathrm{ns}}$ & $0.10^{*}$ & 0.16 & $0.11^{*}$ & $0.11^{*}$ & $0.12^{*}$ & $0.09^{n s}$ & $0.09^{n s}$ & $0.06^{\mathrm{ns}}$ \\
\hline & \multicolumn{13}{|c|}{ Archaeological Dark Earth - Red Ultisol } \\
\hline Mean & 22.0 & 28.4 & 50.4 & 0.8 & 2.6 & 0.92 & 38.30 & 1.7 & 2.5 & 39.54 & 434.1 & 444.3 & 121.5 \\
\hline Median & 22.8 & 28.0 & 50.9 & 0.8 & 2.6 & 0.92 & 37.29 & 1.7 & 2.5 & 39.40 & 442.4 & 432.9 & 120.0 \\
\hline CV (\%) & 37.8 & 11.2 & 12.7 & 9.4 & 3.0 & 0.16 & 0.35 & 20.0 & 10.0 & 19.86 & 13.5 & 16.5 & 35.0 \\
\hline Ass. & 0.2 & 0.8 & 0.7 & -0.4 & 0.3 & 0.23 & 1.07 & 0.3 & -0.3 & -0.27 & -1.1 & 1.1 & 0.6 \\
\hline \multirow[t]{2}{*}{$\mathrm{Nt}$} & $0.09 \mathrm{~ns}$ & $0.08^{\mathrm{ns}}$ & $0.14^{*}$ & $0.08^{*}$ & $0.07 \mathrm{~ns}$ & $0.10^{*}$ & $0.11^{*}$ & $0.10^{*}$ & $-0.07 \mathrm{~ns}$ & $0.06^{\mathrm{ns}}$ & $0.12^{*}$ & $0.12^{*}$ & $0.09 \mathrm{~ns}$ \\
\hline & \multicolumn{13}{|c|}{ Pasture - Red Ultisol } \\
\hline Mean & 17.1 & 20.6 & 37.7 & 1.3 & 2.4 & 2.91 & 24.30 & 2.7 & 3.1 & 15.92 & 410.7 & 227.6 & 361.6 \\
\hline Median & 18.0 & 20.5 & 38.1 & 1.2 & 2.3 & 3.13 & 23.81 & 2.8 & 3.1 & 15.70 & 411.8 & 224.0 & 360.0 \\
\hline CV (\%) & 35.4 & 13.0 & 11.0 & 8.7 & 5.5 & 0.49 & 0.17 & 14.9 & 5.9 & 13.57 & 9.3 & 16.6 & 10.4 \\
\hline Ass. & -0.8 & 0.1 & -0.9 & 0.6 & 0.2 & 0.57 & 1.18 & -2.4 & -2.8 & 0.42 & 0.1 & -0.6 & 0.1 \\
\hline \multirow[t]{2}{*}{$\mathrm{Nt}$} & $0.11^{*}$ & $0.05^{\mathrm{ns}}$ & $0.09 \mathrm{~ns}$ & $0.11^{*}$ & $0.05^{\mathrm{ns}}$ & $0.13^{*}$ & $0.09 \mathrm{~ns}$ & $0.12^{*}$ & $0.15^{*}$ & $0.07 \mathrm{~ns}$ & $0.05^{\mathrm{ns}}$ & $0.08^{\mathrm{ns}}$ & $0.08^{n s}$ \\
\hline & \multicolumn{13}{|c|}{ Agroforestry - Haplic Cambisol } \\
\hline Mean & 2.9 & 30.9 & 33.8 & 1.3 & 2.6 & 4.48 & 30.91 & 2.0 & 2.7 & 11.93 & 220.7 & 230.1 & 549.0 \\
\hline Median & 2.6 & 31.6 & 34.0 & 1.3 & 2.6 & 4.46 & 30.22 & 2.0 & 2.8 & 11.90 & 210.2 & 228.7 & 558.8 \\
\hline CV (\%) & 69.0 & 11.6 & 9.2 & 7.2 & 3.3 & 0.08 & 0.11 & 34.8 & 19.3 & 15.52 & 22.6 & 25.9 & 11.9 \\
\hline Ass. & 0.2 & -0.06 & -0.7 & 0.1 & -0.04 & -0.24 & 2.63 & -0.3 & -3.3 & 0.78 & 1.4 & 0.5 & -0.4 \\
\hline \multirow[t]{2}{*}{$\mathrm{Nt}$} & $0.18^{*}$ & $0.14^{*}$ & $0.14^{*}$ & $0.06^{\mathrm{ns}}$ & $0.10^{*}$ & $0.09 \mathrm{~ns}$ & $0.11^{*}$ & $0.09 \mathrm{~ns}$ & $0.19^{*}$ & $0.08^{\mathrm{ns}}$ & $0.15^{*}$ & $0.12^{*}$ & $0.11^{*}$ \\
\hline & \multicolumn{13}{|c|}{ Sugarcane - Haplic Cambisol } \\
\hline Mean & 7.0 & 29.1 & 36.1 & 1.2 & 2.6 & 4.46 & 32.94 & 2.6 & 3.1 & 17.68 & 240.5 & 474.4 & 284.9 \\
\hline Median & 6.0 & 29.2 & 35.3 & 1.2 & 2.7 & 4.45 & 32.84 & 2.5 & 3.0 & 17.70 & 240.4 & 467.2 & 287.9 \\
\hline CV (\%) & 59.5 & 6.8 & 9.0 & 6.7 & 5.2 & 0.12 & 0.08 & 0.1 & 3.1 & 20.52 & 18.0 & 7.2 & 9.9 \\
\hline Ass. & 1.3 & -0.8 & 1.6 & -0.2 & -0.2 & 1.95 & -0.02 & -0.4 & -0.6 & -0.05 & 0.2 & -0.09 & -0.8 \\
\hline $\mathrm{Nt}$ & $0.14^{*}$ & $0.07^{\mathrm{ns}}$ & $0.12^{*}$ & $0.11^{*}$ & $0.08^{\mathrm{ns}}$ & $0.16^{*}$ & $0.09^{\mathrm{ns}}$ & $0.11^{*}$ & $0.11^{*}$ & $0.07^{\mathrm{ns}}$ & $0.06^{\mathrm{ns}}$ & $0.10^{*}$ & $0.09^{n s}$ \\
\hline
\end{tabular}

CV: coefficient of variation; Ass: Asymmetry; Nt: normality test at $5 \%$ significance by the Kolmogorov-Smirnov test; Macro: macroporosity; Micro: microporosity; TP: total porosity; SBD: soil bulk density; PD: particle density; SRP: soil resistance to penetration; GMD: geometric mean diameter; WMD: mean weight diameter; * and ns: significant and non-significant, respectively. 
soil under sugarcane cropping, found symmetric distributions for these properties.

Soil property variability (Table 2) measured by coefficient of variation (CV) can be considered the first indication of data heterogeneity. The physical properties analyzed showed CV values ranging from low to medium to high values although, in this study, there was a predominance of low and high ones. Our results are in agreement with the results found by Vieira et al. (2011) and Santos et al. (2012), who studied soil physical properties and found medium and high $\mathrm{CV}$ values.

(a)

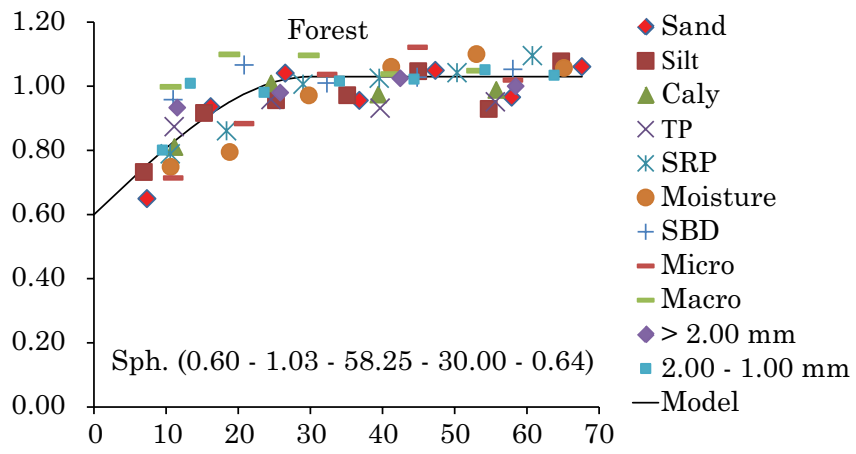

(c)

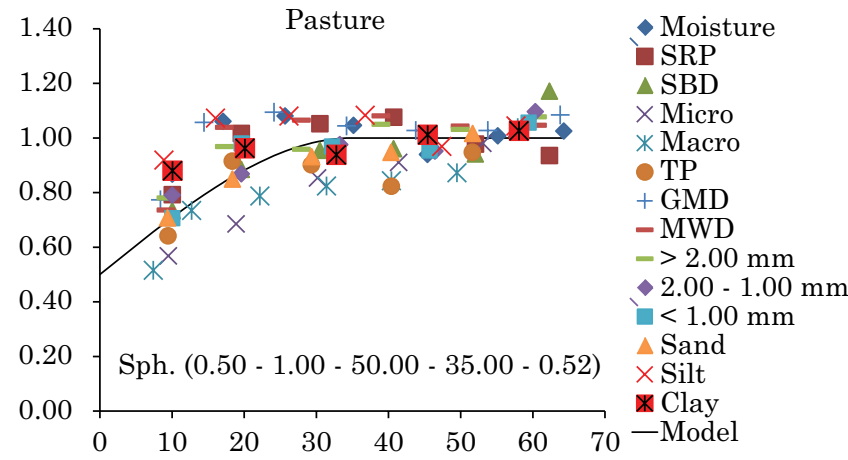

Soil bulk density, PD, SRP and moisture content presented low $\mathrm{CV}$ values for all five environments; TP showed medium CV for ADE and low for the others. In contrast, macroporosity showed high CV for all environments except for forest, which obtained a medium $\mathrm{CV}$. In general, forest $(\mathrm{CV}=9.84 \%)$ and sugarcane $(\mathrm{CV}=11.27 \%)$ environments have low variability in physical properties, while $\mathrm{ADE}$ $(\mathrm{CV}=14.57 \%)$, pasture $(\mathrm{CV}=12.25 \%)$ and agroforestry $(\mathrm{CV}=19.93 \%)$ environments have medium variability (Table 2 ). This implies that in forest and sugarcane environments, there is more

(b)

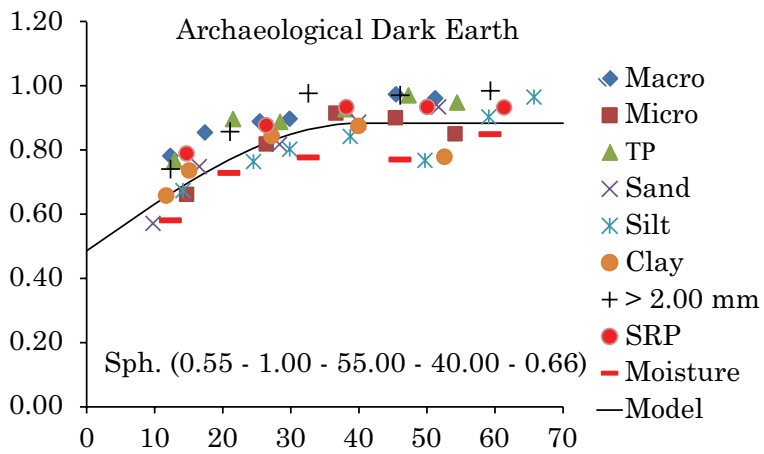

(d)

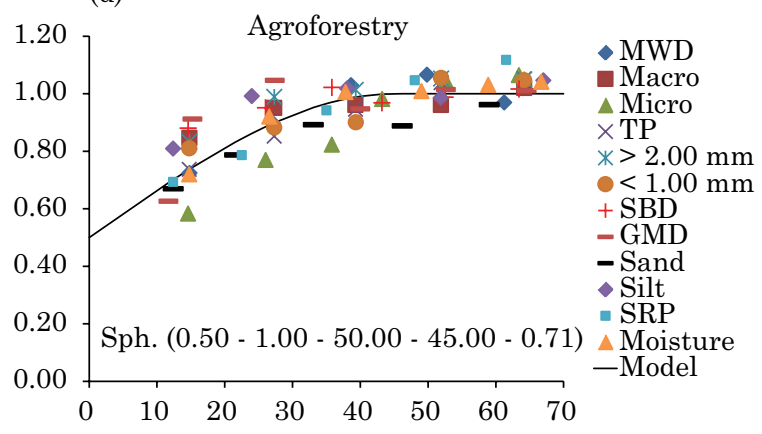

(e)

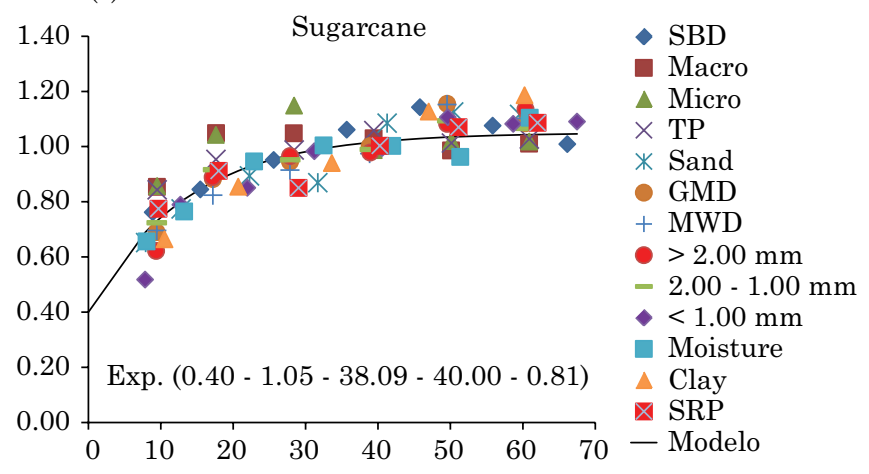

Figure 2. Scaled semivariograms for physical properties of environments in the municipalities of Humaitá and Manicoré in the south of Amazonas. Exp: exponential; Sph: spherical; [model (nugget effect - sill - DSD - $\mathbf{R}^{2}$ - range - residue)]. DSD: Degree of Spatial Dependence; $R^{2}$ : coefficient of determination. 
Table 3. Ideal sampling density and spacing based on estimated range from the scaled semivariograms for soil physical properties in the south of Amazonas

\begin{tabular}{lccccc}
\hline Sample design & Forest & ADE & Pasture & Agroforestry & Sugarcane \\
\hline Sampling density (points ha $\left.{ }^{-1}\right)$ & 11 & 6 & 5 & 8 & 6 \\
Spacing (m) & 30 & 40 & 45 & 35 & 40 \\
\hline
\end{tabular}

ADE: archaeological dark earth.

homogeneity for the properties compared to the other environments.

The Kolmogorov-Smirnov test data showed variations among environments and their properties. Macroporosity had non-normal distribution in all environments, except for ADE. For microporosity, inverse behavior was observed, with non-normal distribution only for agroforestry data. Soil resistance penetration and GMD had normal distribution in the agroforestry area, while WMD showed normality in ADE (Table 2). Campos et al. (2007), studying soil texture in different parent materials, found normality for these properties.

Data normality is not required for application of geostatistical techniques; however, it is advisable that the distribution not have very elongated tails, which could compromise analysis (Isaaks and Srivastava, 1989; Cressie, 1991). Thus, prior exploratory data analysis helps to ensure that these distributions are suitable for geostatistical study.

The continuity of spatial variability of soil texture is less than the continuity of spatial variability of the other physical properties since soil texture is related to the source material, and other physical properties are more easily exchangeable, which may occur, for example, due to tillage and land use (Bottega et al., 2013). Spherical models were fitted to the scaled semivariograms for all areas, with the exception of sugarcane, which was best described by an exponential model (Figure 2). Exponential and spherical models represent medium and low continuity of spatial variability, respectively (Silva and Chaves, 2001). Isaaks and Srivastava (1989) indicate that exponential models are better fitted to erratic phenomena on the small scale, whereas spherical models describe properties with high spatial continuity, i.e., less erratic at short distances.

Similar behavior of geostatistical parameters is observed in the environments under study (Figure 2). In general, the adjusted models showed mean values close to 0.51 nugget effect. Vieira (2000) points out that the greater the nugget effect, the greater the discontinuity among samples. Range values were from $30 \mathrm{~m}$ (forest) to $45 \mathrm{~m}$ (agroforestry). All environments had moderate degrees of spatial dependence (Cambardella et al., 1994). These results are in agreement with results found by Mercante et al. (2003) and Silva Cruz et al. (2010).
Archaeological dark earth and pasture areas showed some dispersal of the experimental semivariograms, indicating different patterns of spatial variability for the variables analyzed (Figure 2). In the other environments, very similar behaviors were observed. On comparing the parameters of the scaled semivariograms of the forest area, a slight variation was seen in relation to the managed environments.

According to Ortiz (2002), knowledge of soil spatial variability, in addition to allowing characterization of a region, may indicate the number and distribution of soil samples to be taken, assisting in detailing the area and in results. Range is an important measure for experimental design and evaluation since it may assist in definition of sampling procedures (Mcbratney and Webster, 1983; Souza et al., 2009). This parameter represents the maximum distance within which sample points are intercorrelated.

Based on range values, the results for minimum sample density and minimum spacing were higher in the forest environment (Table 3). We note that forested areas require a greater number of sample points per hectare (11 points ha-1) compared to areas under anthropogenic management (e.g. $\mathrm{ADE}$, pasture, agroforestry, and sugarcane) for best representation of variability. This may be explained by the absence of human impact within this environment, resulting in greater variability; the agroforestry area likewise follows this trend as it has a forest-like behavior, so its properties have a variability closer to the forest variability.

Obtaining these results presupposes the use of these sampling density and spacing values as a basis for further surveys of soil properties in this region since the locations studied are quite representative in regard to soil type, management practices, and environments across the south of the state of Amazonas.

\section{CONCLUSIONS}

The managed environments showed differences in their physical properties compared to the forest area, especially ADE, which provided better soil physical conditions than the other environments due to its anthropogenic formation. 
All the physical properties evaluated showed a spatial dependence structure, there being a slight variation in the variability of physical properties of the forest compared to the anthropogenic environments. Thus, it can be stated that human practices (soil management) led to changes in the natural variability of soil physical properties.

Use of the range parameter of the scaled semivariogram proved to be effective in determining the optimal sampling density for the environments under study, which may serve as a basis for further soil survey studies in the south of Amazonas.

\section{ACKNOWLEDGMENTS}

The authors would like to thank the FAPEAM, SECTI-AM, and FAPESP for financial support.

\section{REFERENCES}

Andreola F, Costa LM, Olszevski N. Influencia da cobertura vegetal de inverno e da adubação orgânica e, ou, mineral sobre as propriedades físicas de uma Terra Roxa Estruturada. R Bras Ci Solo. 2000;24:857-65.

Barros KRM, Lima HV, Canellas LP, Kern DC. Fracionamento químico da matéria orgânica e caracterização física de Terra Preta de Índio. R Ci Agron. 2012;55:44-51.

Bertol I, Alburquerque JA, Leite D, Amaral AJ, Zoldan Junior WA. Propriedades físicas do solo sob preparo convencional e semeadura direta em rotação e sucessão de culturas, comparadas as do campo nativo. $\mathrm{R}$ Bras Ci Solo. 2004;28:155-63.

Bottega EL, Queiroz DM, Pinto FAC, Souza CMA. Variabilidade espacial de atributos do solo em sistema de semeadura direta com rotação de culturas no cerrado brasileiro. R Ci Agron. 2013;44:1-9.

Brasil. Ministério das Minas e Energia. Projeto RadamBrasil, folha SB. 20, Purus. Rio de Janeiro: Ministério das Minas e Energia, 1978.

Camargo LA, Marques Júnior J, Pereira GT. Mineralogy of the clay fraction of Alfisols in two slope curvatures. IV - Spatial correlation with physical properties. R Bras Ci Solo. 2013;37:307-16.

Cambardella CA, Moorman TB, Novak JM, Parkin TB, Karlen DL, Turco R, Konopka AE. Field-scale variability of soil properties in Central Iowa Soil. Soil Sci Soc Am J. 1994;58:1501-11.

Campos MCC, Aquino EA, Oliveira IA, Bergamin AC. Variabilidade espacial da resistência mecânica do solo à penetração e umidade do solo em área cultivada com cana-de-açúcar na região de Humaitá, Amazonas, Brasil. Agrária. 2013;8:305-10.

Campos MCC, Marques Júnior J, Pereira GT, Montanari R, Siqueira DS. Variabilidade espacial da textura de solos de diferentes materiais de origem em Pereira Barreto, SP. R Ci Agron. 2007;38:149-57.

Campos MCC, Ribeiro MR, Souza Júnior VS, Ribeiro Filho MR, Souza RVCC, Almeida MC. Caracterização e classificação de terras pretas arqueológicas na região do Médio Rio Madeira. Bragantia. 2011;70:18-27.

Campos MCC, Ribeiro MR, Souza Júnior VS, Ribeiro Filho MR, Oliveira IA. Interferências dos pedoambientes nos atributos do solo em uma topossequência de transição Campos/Floresta. R Ci Agron. 2010;41:527-35.

Campos MCC, Oliveira IA, Santos LAC, Aquino EA, Soares MDR. Variabilidade espacial da resistência do solo à penetração e umidade em áreas cultivadas com mandioca na região de Humaitá, AM. R Agro@mbiente. 2012;6:9-16.

Ceddia MB, Vieira SR, Villela ALO, Mota LS, Anjos LHC, Carvalho DF. Topography and spatial variability of soil physical properties. Sci Agric. 2009;66:338-52.

Coelho EC, Souza EG, Uribe-Opazo MA, Pinheiro Neto R. Influência da densidade amostral e do tipo de interpolador na elaboração de mapas temáticos. Acta Sci. 2009;31:165-74.

Cressie N. Statistics for spatial data. New York: John Wiley; 1991.

Empresa Brasileira de Pesquisa Agropecuária - Embrapa. Manual de métodos de análise de solo. Rio de Janeiro: Centro Nacional de Pesquisa de Solos; 1997.

Empresa Brasileira de Pesquisa Agropecuária - Embrapa. Sistema brasileiro de classificação de solos. 3a ed. Brasília: Embrapa Solos; 2013.

Guimarães EC. Variabilidade espacial da umidade e da densidade do solo em um Latossolo Roxo [dissertação]. Campinas: Universidade de Campinas; 1993.

Isaaks EH, Srivastava RM. An introduction to applied geoestatistics. New York: Oxford University Press; 1989.

Kemper WD, Chepil WS. Aggregate stability and size distribution. In: Black CA, editor. Methods of soil analysis. Madison: America Society of Agronomy; 1965. Part.1, p.499. 510. (Agronomy, vol 9).

Kemper WD, Rosenau RC. Aggregate stability and size distribution. In: Klute A, editor. Methods of soil analysis. 2a ed. Madison: American Society of Agronomy; 1986. p.425-1.

Lark RM. Designing sampling grids from imprecise information on soil variability, an approach based on the fuzzy kriging variance. Geoderma. 2000;98:35-9.

Lima JSS, Souza GS, Silva SA. Amostragem e variabilidade espacial de atributos químicos do solo em área de vegetação natural em regeneração. R Árvore. 2010;34:127-36.

McBratney AB, Webster R. How many observations are needed for regional estimation of soil properties. Soil Sci. 1983;135:177-83.

Marins AC, Uribe-Opazo MA, Johann JA. Estimadores New1 e New2 no estudo de dependência espacial da produtividade da soja e atributos físicos do solo de uma área comercial. Eng Agric. 2008;16:133-43.

Marques JDO, Teixeira WG, Reis AM, Cruz Junior OF, Batista $\mathrm{SM}$, Afonso MACB. Atributos químicos, físico-hídricos e mineralogia da fração argila em solos do Baixo Amazonas: Serra de Parintins. Acta Amaz. 2010;40:1-12.

Martins GC, Ferreira MM, Curi N, Vitorino ACT, Silva MLN. Campos nativos e matas adjacentes da região de Humaita (AM): Atributos diferenciais dos solos. Ci Agrotecnol. 2006;30:221-7. 
Matheron G. Principles of geostatistics. Econ Geol. 1963;58:1246-66.

Mercante E, Uribe-Opazo MA, Souza EG. Variabilidade espacial e temporal da resistência mecânica do solo à penetração em áreas com e sem manejo químico localizado. $\mathrm{R}$ Bras Ci Solo. 2003;27:1149-59.

Minitab Release 14.1. Statistical Software [CD-ROM]. Quebec: Canadá; 2000.

Montanari R, Marques Júnior J, Pereira GT, Souza ZM. Forma da paisagem como critério para otimização amostral de Latossolos sob cultivo de cana-de-açúcar. Pesq Agropec Bras. 2005;40:69-77.

Montanari R, Zambianco EC, Corrêa AR, Pellin DMP, Passos E, Carvalho M, Dalchiavon FC. Atributos físicos de um Latossolo Vermelho correlacionados linear e espacialmente com a consorciação de guandu com milheto. R Ceres. 2012;59:125-35.

Neves CMN, Silva MLN, Curi N, Cardoso EL, Macedo RLG, Ferreira MM, Cambardella CA. Atributos indicadores da qualidade do solo em sistema agrossilvopastoril no noroeste do estado de Minas Gerais. Sci For. 2007;74:45-53.

Oliveira IA, Campos MCC, Marques Junior J, Aquino RE, Teixeira DB, Silva DMP. Use of Scaled Semivariograms in the Planning Sample of Soil Physical Properties in Southern Amazonas, Brazil. R Bras Ci Solo. 2015;39:31-9.

Ortiz GC. Aplicação de métodos geoestatisticos para identificar a magnitude e a estrutura da variabilidade espacial de variáveis físicas do solo [dissertação]. Piracicaba: Escola Superior de Agricultura Luiz de Queiroz; 2002.

Santos KS, Montenegro AAA, Almeida BG, Montenegro SMGL, Andrade TS, Fontes Júnior RVP. Variabilidade espacial de atributos físicos em solos do vale aluvial no semiárido de Pernambuco. R Bras Eng Agríc Amb. 2012;16:828-35.

Schaffrath VR, Tormena CA, Gonçalves ACA, Fidalski J. Variabilidade e correlação espacial de propriedades físicas de solo sob plantio direto e preparo convencional. R Bras Ci Solo. 2008;32:1369-77.

Silva Cruz J, Assis Júnior RN, Matias SSR, Camacho-Tamayo JH, Tavares RC. Análise espacial de atributos físicos e carbono orgânico em Argissolo Vermelho-Amarelo cultivado com cana-de-açúcar. Ci. Agrotecnol. 2010;34:271-8.

Silva FWR, Lima HN, Teixeira WG, Motta MB, Santana RM. Caracterização química e mineralogia de solos antrópicos (Terras Pretas de Índio) na Amazônia Central. R Bras Ci Solo. 2011;35:673-81.

Silva PCM, Chaves LHG. Avaliação e variabilidade espacial de fósforo, potássio e matéria orgânica em Alissolos. R Bras Eng Agríc Amb. 2001;5:431-6.
Silva RR, Silva MLN, Ferreira MM. Atributos físicos indicadores da qualidade do solo sob sistemas de manejo na Bacia Alto do Rio Grande-MG. Ci Agrotecnol. 2005;29:719-30.

Soares R. Agregação e distribuição da matéria orgânica em solos de terra preta de índio da Amazônia Central [dissertação]. Niterói: Universidade Federal Fluminense; 2007.

Souza ZM, Marques Júnior J, Pereira GT. Geoestatística e atributos do solo em áreas cultivadas com cana-de-açúcar. $\mathrm{Ci}$ Rural. 2009;40:48-56

Souza ZM, Marques Júnior J, Pereira GT, Montanari R, Campos MCC. Amostragem de solo para determinação de atributos químicos e físicos em área com variação nas formas do relevo. Científica. 2006;34:249-56.

Souza ZM, Marques Júnior J, Pereira GT. Variabilidade espacial da estabilidade de agregados e matéria orgânica em solos de relevos diferentes. Pesq Agropec Bras. 2004;39:491-9.

Steinbeiss S, Gleixner G, Antonietti M. Effect of biochar amendment on soil carbon balance and soil microbial activity. Soil Biol Biochem. 2009;41:1301-10.

Stolf R. Teoria e teste experimental de formulas de transformação dos dados de penetrômetro de impacto em resistência do solo. $\mathrm{R}$ Bras Ci Solo. 1991;15:229-35.

Vieira SR, Dechen SCF, Siqueira GM, Dufranc G. Variabilidade espacial de atributos físicos e químicos relacionados com o estado de agregação de dois Latossolos cultivados no sistema de semeadura direta. Bragantia. 2011;70:185-95.

Vieira SR. Geoestatística em estudos de variabilidade espacial do solo. In: Novais RF, Alvarez V VH, Schaefer CEGR, editores. Tópicos em ciência do solo. Viçosa, MG: Sociedade Brasileira de Ciência do Solo; 2000. v. 1, p.1-54.

Vieira SR. Variabilidade espacial de argila, silte e atributos químicos em uma parcela experimental de um Latossolo Roxo de Campinas (SP). Bragantia. 1997;56:181-90.

Vieira SR, Hatfield JL, Nielsen DR, Biggar JW. Geoestatiscal theory and application to variability of some agronomical properties. Hilgardia. 1983;51:1-75.

Warrick AW, Nielsen DR. Spatial variability of soil physical properties in the field. In: Hillel D, editor. Applications of soil physics. New York: Academic Press; 1980. p.319-44.

Zanão Júnior LA, Lana RMQ, Guimarães EC. Variabilidade espacial do $\mathrm{pH}$, teores de matéria orgânica e micronutrientes em profundidade em um Latossolo Vermelho sob semeadura direta. Ci Rural. 2007;37:1000-7.

Yeomans JC, Bremner JM. A rapid and precise method for routine determination of organic carbon in soil. Commun Soil Sci Plant Anal. 1988;19:1467-76. 